\title{
Extensive Atypical HSV-2 Ulceration of the Finger
}

\section{Úlcera Digital Atípica Causada por HSV-2}

Nélia CUNHA $\rrbracket^{1}$, Pedro SIMÕES ${ }^{2}$, Vasco SERRÃO ${ }^{1}$

Acta Med Port 2017 Jul-Aug;30(7-8):587-587 - https://doi.org/10.20344/amp.9206

Keywords: Acquired Immunodeficiency Syndrome; Fingers; Herpesvirus 2, Human; HIV; Ulcer

Palavras-chave: Dedos; Herpesvirus Humano 2 Síndrome de Imunodeficiência Adquirida; Úlcera; VIH

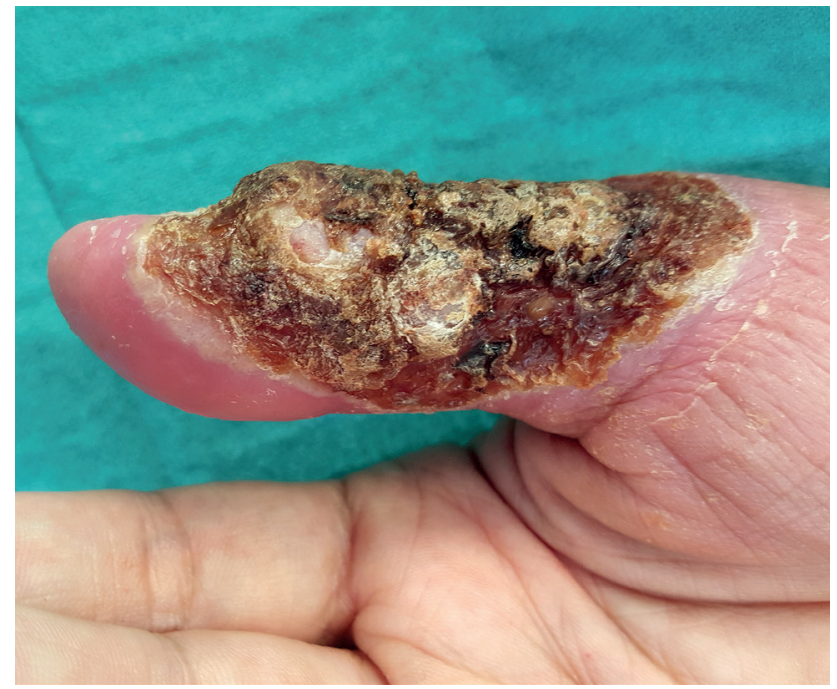

Figure 1 - Large and painful ulceration of the right first finger, evolving for more than one month

A 56-year-old man presented with a large and painful ulceration of the right first finger evolving for more than one month (Fig. 1). The patient had a known human immunodeficiency virus (HIV) infection for four years, but had discontinued antiretroviral treatment in the last year. Histological examination revealed balooning degeneration of keratinocytes. Immunohistochemical stain for herpes simplex virus (HSV) was positive (Fig. 2). HSV type 2 DNA was detected by polymerase chain reaction (PCR). Culture and PCR for mycobacteria were negative. Syphilis

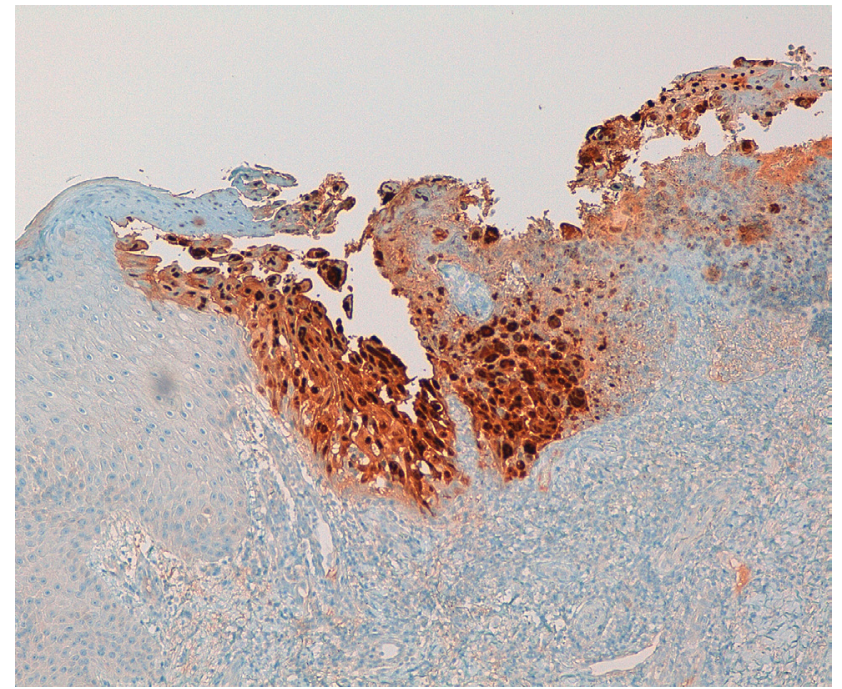

Figure 2 - Immunohistochemical stain for herpes simplex virus (HSV) was positive

serology was consistent with treated syphilis. HIV load was $284000 \mathrm{Ul} / \mathrm{mL}$, and CD4 cells were $14 / \mathrm{mm}^{3}$. Resolution of the ulcer was obtained after 28 days of oral acyclovir and reintroduction of antiretroviral therapy.

In immunocompromised patients, HSV skin lesions can be larger, atypical, necrotic, and should be treated until complete resolution. ${ }^{1-3}$ Non-healing herpetic ulcers for longer than one month is an acquired immunodeficiency syndrome-defining condition. ${ }^{4}$

\section{REFERENCES}

1. Hogan MT. Cutaneous infections associated with HIVIAIDS. Dermatol Clin. 2006;24:473-95.

2. Robayna MG, Herranz P, Rubio FA, Peña P, Peña JM, González J, et al. Destructive herpetic whitlow in AIDS: report of three cases. Br J Dermatol. 1997;137:812-5.

3. Centers for Disease Control and Prevention. Sexually transmitted diseases treatment guidelines, 2015. MMWR Recomm Rep. 2015;64:1-137.

4. Centers for Disease Control and Prevention. 1993 revised classification system for HIV infection and expanded surveillance case definition for AIDS among adolescents and adults. MMWR Recomm Rep. 1992;41:1-19.

\footnotetext{
1. Dermatology Department. Hospital de Santo António dos Capuchos. Centro Hospitalar de Lisboa Central. Lisboa. Portugal.

2. Department of Infectious Diseases. Hospital de Curry Cabral. Centro Hospitalar de Lisboa Central. Lisboa. Portugal.

$\bowtie$ Autor correspondente: Nélia Cunha. nelia.margarida.cunha@gmail.com

Recebido: 21 de maio de 2017 - Aceite: 14 de julho de 2017 | Copyright @ Ordem dos Médicos 2017
} 